\title{
MINERAL RESOURCE POTENTIAL AND GEOLOGY OF THE DOLUS LAKES ROADLESS AREA, POWELL AND GRANTTE COUNTIES, MONTANA
}

\author{
By \\ James E. Elliott, Michael R. Waters, and Wealey L. Campbell, \\ U. S. Geological Survey \\ and \\ Dale W. Avery, U. S. Bureau of Mines
}

\section{STUDIES RELATED TO WILDERNESS}

Under the provisions of the Wilderness Act (Public Law 88-577, September 3, 1964) and related acts, the U.S. Geological Survey and the U.S. Bureau of Mines have been conducting mineral surveys of wilderness and primitive areas. Areas officially designated as "wilderness," "wild," or "canoe" when the act was passed were incorporated into the National Wilderness Preservation System, and some of them are presently been studied. The act provided that areas under consideration for wilderness designation should be studied for suitability for incorporation into the Wilderness System. The mineral surveys constitute one aspect of the suitability studies. The act directs that the results of such surveys are to be made available to the public and be submitted to the President and the Congress. This report discusses the results of a mineral survey of the Dolus Lakes Roadless area, Deerlodge National Forest, Powell and Granite Counties, Mont. The Dolus Lakes Roadless Area (01429) was classified as a further planning area during the second Roadless Area Review and Evaluation (RARE II) by the U.S. Forest Service, January 1979.

\section{MINERAL RESOURCE POTENTIAL SUMMARY STATEMENT}

A mineral survey of the Dolus Lakes Roadless Area, an area of about $14 \mathrm{mi}^{2}$ in the Flint Creek Range of southwestern Montana, was conducted by the U. S. Bureau of Mines in 1981 and by the U. S. Geological Survey in 1980,1981 , and 1982. Results of this survey indicate that the roadless area has significant mineral resource potential. Two subareas have high potential for the occurrence of resources of gold, silver, and molybdenum. One subarea has moderate potential for the occurrence of resources of gold, silver, and molybdenum; one subarea has moderate potential for the occurrence of tungsten plus these same commodities; and the remainder of the roadless area has low potential for the occurrence of tungsten, gold, silver, and molybdenum.

One of the areas assigned high potential, the Pikes Peak-Rose Mountain area (area 1, fig. 2), has identified resources of about 57,000 tons containing gold and silver. The other area assigned high potential, the Tolean Lake-Game Pass area (area 2), has identified resources of 6 million tons of subeconomic molybdenum-bearing rock that averages 0.036 percent molybdenum disulfide ( $\left.\mathrm{MOS}_{2}\right)$.

Types of deposits that are known or expected to occur in the roadless area are vein gold and silver, stockwork molybdenum, skarn tungsten, and placer gold.

The roadless area has low potential for the occurrence of sand, gravel, stone, and phosphate resources. On the basis of the nature of the geologic terrain, the potential for geothermal, coal, oil, or gas resources is determined to be low.

\section{INTRODUCTION}

\section{Geography and location}

The Dolus Lakes Roadless area is in mountainous terrain of southwestern Montana, about $12 \mathrm{mi}$ west of Deer Lodge and about $35 \mathrm{mi}$ northwest of Butte (fig. 1). The area of about $14 \mathrm{mi}^{2}$ (about 9,000 acres) is part of the Deerlodge National Forest, Powell and Granite Counties. The roadless area forms the northeastern part of the Flint Creek Range and adjoins the Flint Creek Range Wilderness Study Area, separated from it by a narrow corridor along Rock Creek. The Flint Creek Range is an impressive range of mountains west of Deer Lodge that can be viewed by the traveler from Interstate Highway 90 between Deer Lodge and Butte.

The topography of the roadless area is dominated by a horseshoe-shaped mountain mass, open to the east, that includes Pikes Peak, the highest point in the roadless area, with an elevation of $9,359 \mathrm{ft}$. The center of this horseshoe is a glaciated valley containing east-flowing Dolus Creek and the three Dolus Lakes. Many of the peaks and ridges in and 


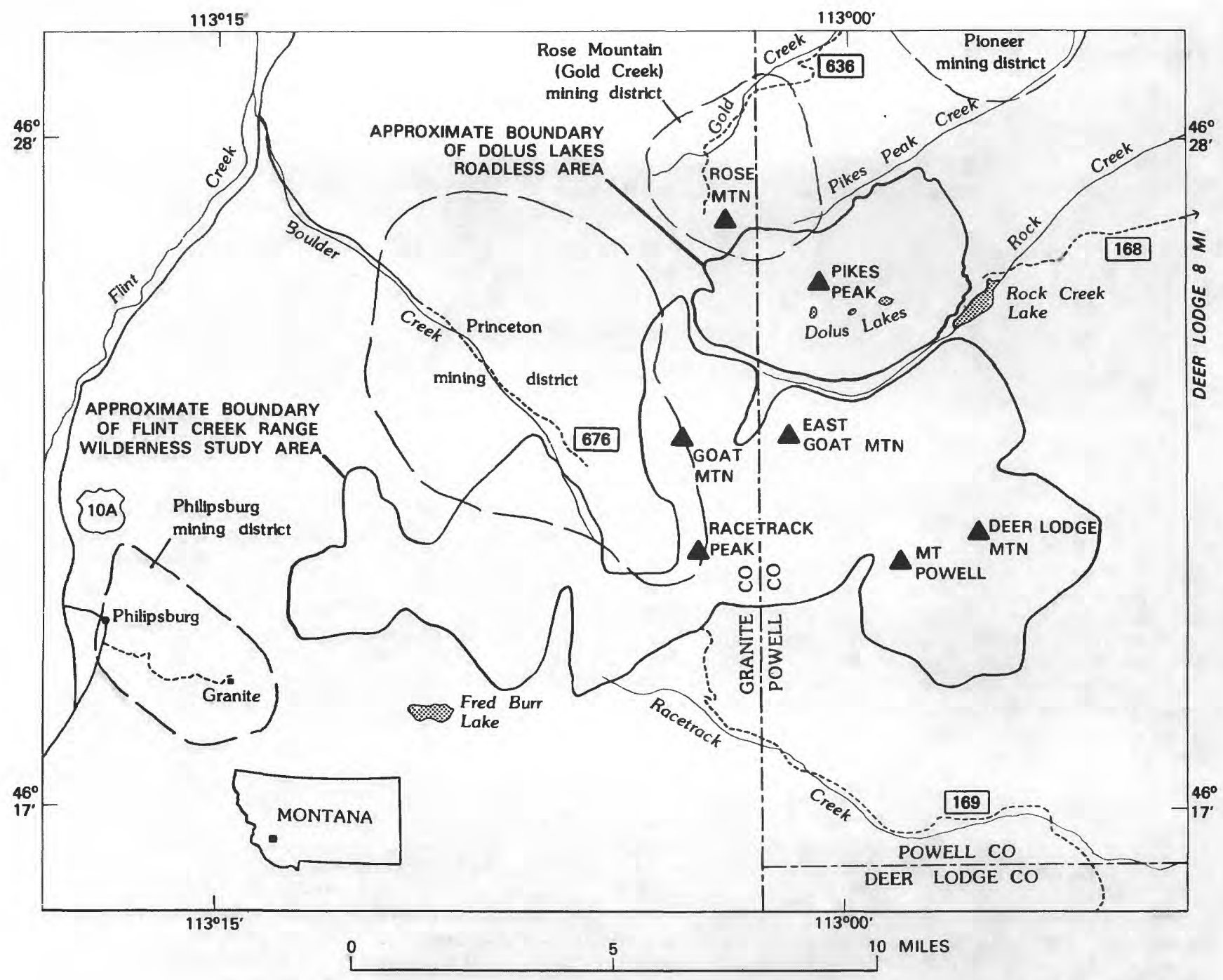

Figure 1.-Index map showing location of the Dolus Lakes Roadless Area (01429), Powell and Granite Counties, Mont. 
adjacent to the roadless area are above timberline, in most places about $8,500 \mathrm{ft}$, but the lower slopes and stream valleys are tree and brush covered. The lowest elevation in the roadless area is about $6,000 \mathrm{ft}$, in the valley of Rock Creek near Rock Creek Lake.

Rock Creek drains the southern part of the roadless area, and Pikes Peak Creek drains the northern. Much of the interior of the roadless area is drained by Dolus Creek. Access to the eastern and northern borders of the roadless area is by gravel and dirt roads from Deer Lodge or Gold Creek. The western and southern boundaries of the area are accessible by walking or jeep trails.

\section{Previous studies}

Previous work in and adjacent to the Dolus Lakes Roadless Area includes geologic mapping and studies of mineral resources and various aspects of the geology. The western part of the roadless area, west of long $113^{\circ}$ W., was mapped and the geology and ore deposits described by Emmons and Calkins (1913). The remainder of the roadless area is part of the northeast flank of the Flint Creek Range, which was mapped and described by Mutch (1960). Reports by Allen (1966), Benoit (1974), and Baty (1976) discussed the structure, petrology, chemistry, and ages of intrusive rocks that are exposed over most of the roadless area. The mineral resource potential of the Flint Creek Range Wilderness Study Area, which adjoins the Dolus Lakes area on the south and southwest (fig. 1), was described by Ericksen and others (1981). Pardee (1951) and Lyden (1948) described the historically productive placers of Gold Creek and the Pioneer mining district, which were exploited along streams originating in the roadless area.

\section{Present studies}

The mineral resource evaluation of the roadless area is based on geologic mapping, geochemical mapping, and the investigation of mines and prospects. No new geophysical studies were conducted for this evaluation; however, results from other studies (Douglas, 1973; Hassemer and Hanna, 1982) were utilized. Previous geologic mapping was inadequate for the purposes of this study, so the entire roadless area was remapped by the U.S. Geological Survey during 1980 and 1981 and compiled at a scale of 1:50,000. During 1981 and 1982 the U.S. Geological Survey conducted the geochemical survey. During 1981 the U.S. Bureau of Mines investigated mines and prospects in or adjacent to the roadless area.

\section{Geologic setting}

The dominant rock type, exposed prominently in the high peaks and ridges of the roadless area, is granodiorite of the Royal stock, the northernmost of three major plutons of the Flint Creek Range. The other plutons are the Philipsburg and Mount Powell batholiths. The Royal stock has intruded Paleozoic and Mesozoic sedimentary rocks along the north boundary of the roadless area and in the eastern part of it (fig. 2). Along the southeast and south sides of the roadless area, the granodiorite stock intruded sedimentary rocks of Proterozoic age and was intruded by monzogranite of the Mount Powell batholith, which extends south to form much of the eastern and southeastern parts of the Flint Creek Range. The internal structure of the Royal stock is relatively simple, consisting of joints and narrow shear zones; that of the sedimentary rocks, however, is complex and consists of large isoclinal and recumbent folds, thrust faults, and normal faults. These structures are best seen in Emery Ridge, just north of the roadless area. The sedimentary rocks were contact metamorphosed by the granodiorite stock; limestone was converted to marble, and shale and siltstone to hornfels. Quaternary alluvium and glacial till of at least two ages are present in stream valleys and on benchlands bordering the roadless area to the east.

\section{GEOLOGY}

\section{Middle Proterozoic rocks}

The Helena, Mount Shields, and Garnet Range Formations, of the Belt Supergroup of Proterozoic age, crop out on the ridge southeast of the roadless area and on the south side of Rock Creek Lake (fig. 2). The Helena Formation consists of light-gray-, greenishgray-, and tan-weathering limestone, limy siltstone, and shale; these lithologies were mostly converted to calc-silcate hornfels and marble by contact metamorphism. Although about $5,000 \mathrm{ft}$ of the Helena Formation is exposed on the ridge, the maximum thickness in this region is about 9,000 ft (C. A. Wallace, written commun., 1983).

The Mount Shields Formation is part of the Missoula Group, which overlies the Helena Formation. The Mount Shields Formation consists of three members, but only the middle member is present in the roadless area. About $1,600 \mathrm{ft}$ of this member is in thrust contact with the Helena Formation and is exposed on the ridge southeast of the roadless area. Elsewhere in the region the middle member ranges in thickness from about $3,700 \mathrm{ft}$ to $5,300 \mathrm{ft}$. Regionally, most of the middle member is massive-weathering, thick-bedded, $\tan$ quartz arenite, subarkose, and arkose. In the Flint Creek Range, most of the middle member is granule-bearing, medium- to coarse-grained sandstone containing minor pebble conglomerate and argillite interbeds (C. A. Wallace, written commun., 1983).

About 1,200 ft of the Garnet Range Formation is exposed along the south shore of Rock Creek Lake as part of a sequence, which includes Cambrian rocks, that is overturned and dipping to the east. To the south, this sequence is overlain by, and is in thrust contact with, the Helena Formation. The Garnet Range Formation is a sequence of green to grayishgreen, thinly bedded silty argillite, argillaceous siltstone, and silty sandstone. Where complete, the maximum thickness is about $4,500 \mathrm{ft}$, but only the upper part is exposed along Rock Creek Lake. Here it is micaceous and has a fairly well developed schistosity as a result of folding and contact metamorphism.

\section{Paleozoic rocks}

Rocks of Paleozoic age are exposed on Emery Ridge, north of the roadless area, and along the east 


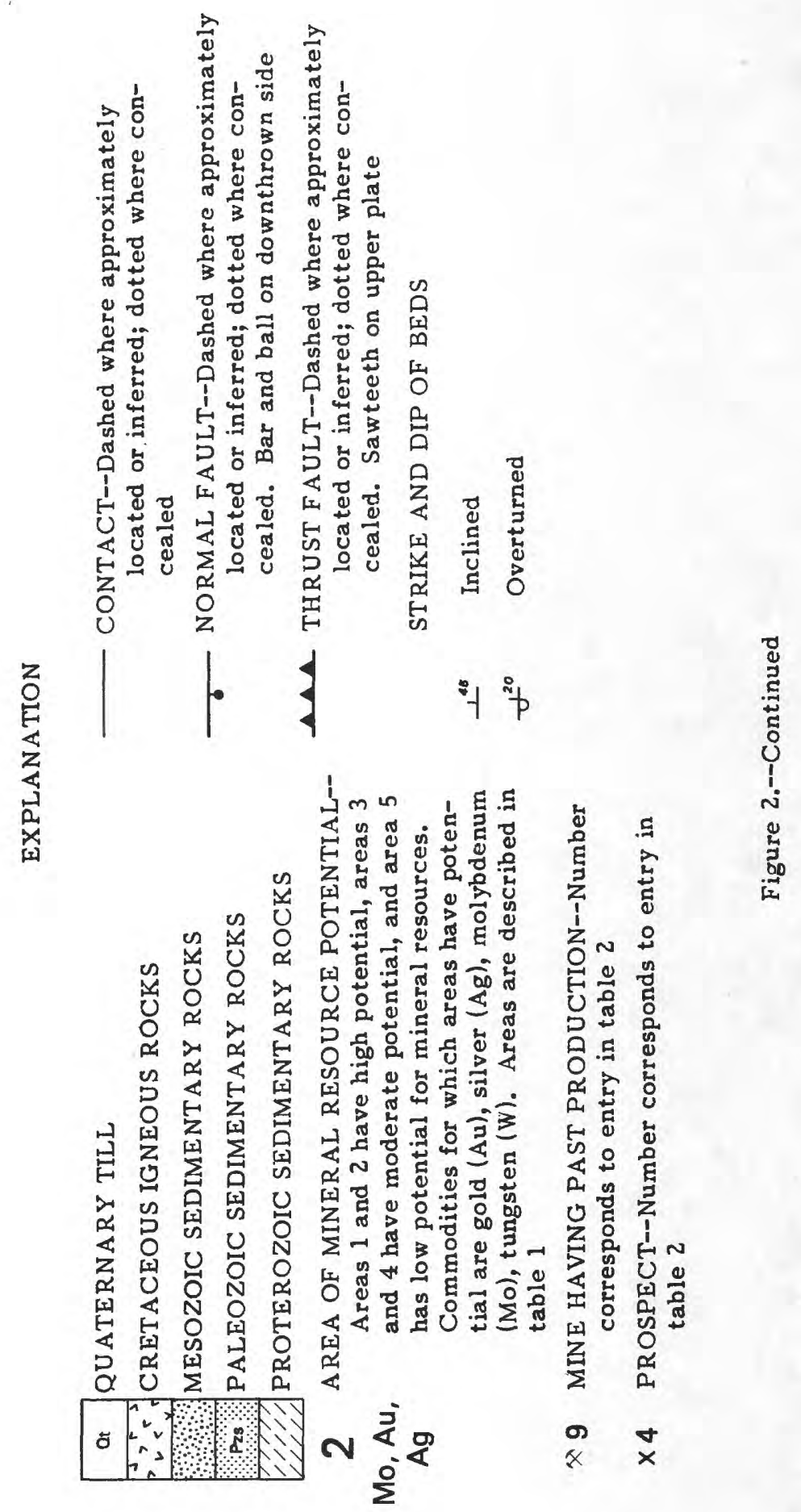


side of the roadless area from Pikes Peak Creek to Rock Creek Lake (fig. 2). Cambrian, Mississippian, and Pennsylvanian formations crop out in the roadless area, and rocks of Permian age crop out on Emery Ridge. Cambrian rocks include the Flathead Quartzite and Silver Hill Formation of Middle Cambrian age and the Hasmark Formation of Late Cambrian age. The Mission Canyon Limestone, part of the Madison Group, is Mississippian in age. Rocks of Pennsylvanian age include the Amsden and Quadrant Formations, and the Phosphoria Formation, exposed on Emery Ridge, is Permian in age. Information on the lithologies and thicknesses of the Paleozoic and Mesozoic units for this region of Montana was provided by C. A. Wallace (written commun., 1983).

Cambrian rocks are exposed along the eastern margin of the roadless area, along the northwest and southwest shores of Rock Creek Lake, and on the slopes above the lake. Outcrops along the lake are a sequence of Flathead Quartzite, Silver Hill Formation, and Hasmark Formation in contact with granodiorite of the Royal stock and with the Garnet Range Formation. The Flathead Quartzite is tan-weathering, well-sorted, rounded to subrounded, fine- to mediumgrained, crossbedded quartzite. Regionally this unit unconformably overlies the Belt Supergroup and varies from 0 to $65 \mathrm{ft}$ in thickness; it is about $60 \mathrm{ft}$ thick in the roadless area.

The Silver Hill Formation overlies the Flathead Quartzite and, where not metamorphosed, consists of a lower unit of sandstone, siltstone, and shale; a middle unit of limestone; and an upper unit of shale. The lower unit is dominantly grayish-black to grayish-olive shale containing lenticular sandstone beds, about 1 in. to $3 \mathrm{ft}$ thick, and siltstone laminae and beds from 0.05 in. to about 1 in. thick, which display flaser-like structure. The thickness of this unit ranges from about 30 to $90 \mathrm{ft}$. The middle unit is grayish-blue limestone that contains reddish-orange-weathering lenticular ribbons and pods of silty and sandy dolomite. This limestone has flaggy parting and is gradational at top and bottom with overlying and underlying shale; its thickness generally ranges from about 120 to $190 \mathrm{ft}$. The upper unit is a green, waxy shale, now hornfels, that is generally about 9 to $18 \mathrm{ft}$ thick. The total thickness of the Silver Hill Formation in the roadless area is about $255 \mathrm{ft}$.

The Upper Cambrian Hasmark Formation overlies the Silver Hill Formation in exposures around Rock Creek Lake. Regionally this unit is mostly finegrained, gray or yellowish-gray dolomite, locally calcitic, and commonly containing a little interbedded shale. Where complete, the formation is about $900 \mathrm{ft}$ thick; nearly all of this unit is exposed in the roadless area.

Overlying the Hasmark and separated from it by a thrust fault is the Mission Canyon Limestone, the upper part of the Madison Group of Mississippian age. This unit crops out on steep, timbered slopes along the east side of the roadless area and in the core of a recumbent fold on Emery Ridge north of the roadless area. It consists of well-bedded, richly fossiliferous, light- to medium-gray limestone that locally contains black chert concretions. Where complete, this carbonate unit is as thick as 2,300 ft, but only about $1,800 \mathrm{ft}$ are exposed in the roadless area.
The Amsden Formation of Pennsylvanian age overlies the Mission Canyon Limestone and crops out in the recumbent anticline on Emery Ridge. The Amsden also occurs with the Quadrant Formation in a small roof pendant in the Royal stock on Pikes Peak Ridge. Where not metamorphosed and complete, as it is in the roadless area, the Amsden consists of a sequence of red shale, siltstone, sandstone, and minor gray limestone, about $300 \mathrm{ft}$ thick.

The Quadrant Formation is gradational with the underlying Amsden Formation, is 60-100 ft thick, and is mainly brown-weathering massive quartzite. It is resistant, commonly forming ridges, and is a vitreous, well-sorted, angular to subangular, fine- to mediumgrained quartz arenite. It is present both in the roadless area and on Emery Ridge, where it is about $85 \mathrm{ft}$ thick.

The Phosphoria Formation of Permian age is economically important in the region because it contains bedded phosphorite. Major amounts of phosphatic rock have been mined from the Phosphoria in the Douglas Creek mining district, about $6 \mathrm{mi}$ northwest of the Dolus Lakes Roadless Area, and from the Garrison mining district, about $12 \mathrm{mi}$ to the northeast. The Phosphoria Formation is not exposed in the roadless area but is exposed on Emery Ridge north of the roadless area. Regionally, the formation ranges between 150 and $190 \mathrm{ft}$ thick and consists of a varied assemblage of light- to dark-gray rocks: sandstone, shale, shaly limestone, phosphorite, and phosphatic limestone. The Phosphoria is about $170 \mathrm{ft}$ thick in the section exposed on Emery Ridge.

\section{Mesozoic sedimentary rocks}

The only Mesozoic sedimentary rocks that crop out in the roadless area are exposed in the northeastern part and are correlated with the Ellis Group of Jurassic age. However, rocks belonging to this group and to the Kootenai Formation of Cretaceous age are exposed over much of Emery Ridge. The Ellis Group is separated from the underlying Phosphoria by a regional unconformity and ranges between 540 and $550 \mathrm{ft}$ thick. The Ellis Group includes the Sawtooth, Rierdan, and Swift Formations, which consist of sandstone, siltstone, and shale and minor shaly and sandy limestone and conglomerate.

The Kootenai Formation of Early Cretaceous age disconformably overlies the Swift Formation on Emery Ridge, where faulted but nearly complete sections are present. Regionally, the Kootenai is about $900 \mathrm{ft}$ thick. This formation consists of alternating clastic and limestone units. Clastic units are red and green sandstone, siltstone, and shale. The distinctive upper limestone unit contains abundant gastropod fossils.

Shale and sandstone of the Blackleaf Formation of Early Cretaceous age overlie the Kootenai Formation elsewhere in the region but are not present in the roadless area. The Blackleaf is inferred to be present in the subsurface north of the roadless area.

\section{Cretaceous intrusive rocks}

The Royal stock, exposed over most of the roadless area, extends to the west and southwest, covering a total area of about $30 \mathrm{mi}^{2}$. It was 
described as a biotite granite by Emmous and Calkins (1913). In the IUGS system (Streckeisen, 1975), used in this report, the modal composition of the stock is predominantly granodiorite. The Royal stock has an indicated fission-track age of $67 \mathrm{~m} . y$. (Baty, 1976), and work in progress by the potassium-argon method confirms a Late Cretaceous age (J. D. Obradovich, unpub. data). The granodiorite is light gray, allotriomor phic granular to hypidiomorphic granular, in places weakly porphyritic, and is medium grained, generally in the range of 1 to $4 \mathrm{~mm}$. Emmons and Calkins (1913) noted that the stock is locally gneissic near the margins and cut by aplite dikes. Plagioclase (47 percent), potassium feldspar (18 percent), and quartz ( 26 percent) are the principal minerals (Allen, 1966). Biotite is the only mafic mineral, averaging about 8 percent. The plagioclase is mostly normally zoned andesine. A little muscovite (less than 1 percent) is commonly present, and the accessory minerals are apatite, magnetite, zircon, sphene, and monazite. Minor sericitic and propylitic alteration is present at some localities, and more intense alteration is seen in areas of mineralization. The stock has a contact metamorphic aureole, with a maximum width of $1 \mathrm{mi}$, in the surrounding sedimentary rocks. Discordance of the stock to regional structures indicates forceful intrusion (Allen, 1966).

Abundant quartz veins in the Royal stock represent barren quart $z$, quartz-limonite, and quartzsulfide types. Sulfide minerals identified in these veins are pyrite, molybdenite, galena, chalcopyrite, sphalerite, and bismuthinite. The quartz veins have been emplaced along joints and shear zones; they generally are in the range of $0.5 \mathrm{in}$. to $1 \mathrm{ft}$ in thickness and rarely are 1-3 ft thick. These veins are most abundant in two areas: (1) the area between Tolean Lake and Game Pass, where a stockwork of closely spaced veins is found; and (2) a zone of northwesterly trending, parallel veins extending from Pikes Peak to Rose Mountain; these are spaced tens to hundreds of feet apart. Elsewhere in the roadless area, veins are common but more widely spaced.

Rocks of the Mount Powell batholith are exposed south of the roadless area on the upper slopes of the valley of Rock Creek. This batholith occupies an area of slightly more than $50 \mathrm{mi}^{2}$ across much of the eastcentral and southeastern parts of the Flint Creek Range. The rock is porphyritic muscovite-biotite granite (Emmons and Calkins, 1913) that has a modal composition ranging from monzogranite to granodiorite in the IUGS system. The age of this batholith is about 62 m.y., based on fission tracks in apatite, and work in progress indicates an age of about $63 \mathrm{~m} . y$. by the potassium-argon method (J. D. Obradovich, unpub. data). These ages span the Cretaceous-Tertiary boundary, but because they are minimum ages that record the cooling and crystallization of the batholith, a Cretaceous age is assigned for emplacement of this pluton.

Rocks of the Mount Powell batholith are generally very light gray, medium to coarse grained, allotriomorphic granular, and slightly to strongly porphyritic, containing potassium feldspar crystals commonly as long as several centimeters. The essential minerals are plagioclase (43 percent), potassium feldspar (19 percent), quartz ( 32 percent), biotite (4 percent), and muscovite ( 2 percent); accessories are apatite, magnetite, and zircon. Plagioclase is mostly normally zoned oligc -lase. Minor to moderate alteration of plagioclase and biotite is common. The batholith is accompanied by abundant pegmatite and aplite dikes, many of which contain muscovite and garnet in addition to quartz and feldspar. Quartz veins are rare in the llount Powell batholith.

Field relations indicate that the Mount Powell batholith is younger than and intrude the Royal stock. Chemical analyses of whole-rock samples of the two plutons show each to be intisnally quite homogeneous and chemically distinct from the other, but a few samples taken from near the c ntact of the two plutons suggest a gradational relationship (Benoit, 1974). This and other chemical and mineralogical evidence suggests that the Mount Powell is a later, more silicic and felsic differentiate of the same magma that produced the Royal stock (Benoit, 1974).

\section{Quaternary deposits}

Deposits of Quaternary age, predominantly glacial till, are widespread in the roadless and surrounding areas, occupying stream vallevs that drain the area or mantling terraces that border the east side of the roadless area. Most of these deposits are of glacial origin but they include minor alluvial deposits formed along the present streams since glaciation.

Two ages of glacial deposits are renognized and differentiated by geomorphic form, the relative proportions of sedimentary to igneous clasts, and the degree of weathering of the igneous clasts. The early glacial till has been mapped along the steep eastern side of the roadless area and on terraces east, northeast, and southeast of the roadless area; no morainal topography is preserved in these deposits. In this older till, clasts of sedimentary rocks predominate over those of igneous rocks, and the latter are highly weathered. The late glacial till forms well preserved lateral and terminal moraines, mainly along stream valleys. In this till, clasts of igneous rocks, which are predominantly unweathered, are much mre abundant than clasts of sedimentary rocks.

The distinction in the age of glacial deposits is important because in the Pioneer district to the northeast most of the placer-gold deposits seem related to the earliest glacial stage. Pardee (1951) distinguished three stages of glaciation, all of which had a source in the vicinity of the roadlers area. The earliest stage was responsible for most of the gold that was transported by glaciers to the vicinity of the Pioneer district. This gold probably came from veins in sedimentary rocks in the roof zone of the Royal stock, which were stripped off by the glaciers. In two later stages of glaciation, an intermediate till containing moderate amounts of gold ard a late till containing relatively little gold were deposited. The intermediate stage of glacial till was not recognized in the roadless or surrounding areas, but if present it is probably included in what was mapped as early till. According to Pardee (1951) this intermediate till is distinguished by a preponderance of metasedimentary rocks. 
Structure

Sedimentary rocks of the roadless and surrounding areas are strongly deformed by folding and faulting. Structures are best seen on Emery Ridge to the north where several thrust faults, a normal fault, and recumbent folds occur in the Paleozoic and Mesozoic units. Thrust faults have also been mapped in the eastern part of the roadless area and southeast of it. In the northeastern part of the roadless area, a normal fault juxtaposes Jurassic and Mississippian rocks.

Structures seen in the sedimentary section belong to a regional thrust system called the Sapphire plate (Ruppel and others, 1981). This system is characterized by structures of several types: anastomosing imbricate thrust faults; numerous younger-over-older thrusts; mixed steep and flat, west-dipping thrusts and some east-dipping thrusts; isoclinal, overturned folds; and breccia along sole zones of thrust faults. Based on radiometric and stratigraphic evidence, the age of thrusting is Late Cretaceous. East transport of at least $70 \mathrm{~km}$ is suggested for the western part of the Sapphire plate (Ruppel and others, 1981).

The Royal stock was emplaced in the sedimentary section near the end of the Cretaceous Period after active thrusting had ceased. Evidence that emplacement was post-tectonic is the general lack of structure in the granodiorite stock and the truncation by the stock of thrust and normal faults in the sedimentary rocks. Structural and petrologic features are consistent with forceful intrusion of the stock (Allen, 1966). A prominent set of primary joints strikes about N. $65^{\circ} \mathrm{W}$. and dips $55^{\circ} \mathrm{SW}$. (Allen, 1966). Aplite dikes and quartz veins, many of which were mineralized, parallel this joint set. A zone in the granodiorite of crushing and shearing accompanied by intense foliation of unknown extent and origin trends north-northeast through an exposure on Rock Creek (Emmons and Calkins, 1913).

\section{GEOCHEMISTRY}

Evaluation of the mineral resource potential of the roadless area is partly based on 180 geochemical samples. These samples consisted of 35 panned concentrates of stream sediments, 35 fine-grained stream-sediment samples, 22 soil samples, and 88 rock samples. Panned-concentrate and stream-sediment samples were collected at the same sites from alluvium in first- and second-order streams. Soil samples and the stream-sediment samples were sieved through an 80-mesh sieve, and only material that passed through the sieve was analyzed. Soil and rock samples were collected along ridge crests and in or near mineralized areas. All the samples were analyzed by a six-step semiquantitative emission-spectrographic procedure for 31 elements. Selected samples were analyzed by wet-chemical methods for copper, lead, zinc, tungsten, cadmium, bismuth, antimony, arsenic, gold, and mercury. The geochemical data and pertinent geological parameters were stored on magnetic disc in the U.S. Geological Survey's computer in Denver, Colo. Computer treatment of the analytical data included graphical analyses, frequencydistribution plots of the concentrations of various elements, correlation analyses, factor analyses, and other statistical computations. Geochemical dita applicable to mineral resource potential are presen ${ }^{+} . e d$ here.

In panned concentrates, anomalies were found for gold, silver, copper, lead, zinc, bismuth, molybdenum, tungsten, boron, beryllium, cobalt, nickel, and vanadium. The most notable anomalies, particularly for tungsten, lead, copper, and bismuth, were in samples from along Rock Creek; and for silver, copper, lead, zinc, bismuth, and boron in samples from sec. 24, T. 8 N., R. 12 W. Gold anomalies were also present in samples from sec. 24, T. 8 N., R. 12 W., from streams near Doney Lake, and from along Pikes Peak Creek. In stream sediment and soil samp]rs, anomalies were found for silver, copper, lead, zinc, molybdenum, tungsten, boron, beryllium, manganese, cadmium, and bismuth. Stream-sediment samples from the Dolus Creek drainage basin were anomalous in silver, copper, lead, and zinc. Samples from the Rock Creek drainage basin were anomalous in many elements, including silver, copper, lead, zinc, molybdenum, tungsten, beryllium, boron, and manganese. Soil samples taken along the ridge in secs. $23,24,27$, and 34, T. 8 N., R. 12 W., were anomalous in silver, copper, lead, molybdenum, zinc, and other elements. Geochemical anomalies in rock samples were found at many localities for one or more of the following elements: gold, silver, copper, lead, zinc, arsenic, cadmium, bismuth, antimony, molybden $n$, tungsten, manganese, boron, beryllium, chromir' $n$, lanthanum, nickel, tin, and vanadium. The most abundant anomalies are for the base and precious metals, as shown not only by spectrographic analyses, but also by wet-chemical analyses. Nearly all the rnck samples were anomalous in one or more elements. The strongest anomalies were in samples from along Pikes Peak ridge in secs. 20,29 , and 30, T. 8 N., R. 11 W., and the ridge in secs. $23,26,27$, and $34, T$. 8 N., R. $12 \mathrm{~W}$. Most of the anomalies were in samples fr?m the Royal stock or in contact zones of the stock with sedimentary rocks. Anomalies of molybdenum and tungsten were found in samples from several localities, but anomalies of both metals in samples from the same sites were uncommon. Anomalous concentrations of boron, beryllium, chromium, lanthanum, nickel, tin, and vanadium commonly were associated with anomalous concentrations of molybdenum, tungsten, or of precious metals or base metals.

Correlation analyses (VanTrump and Mies $h$, 1977) were done on the analytical data to determine geochemical associations that might be related to mineralizing processes. In panned-concentrate samples, correlation coefficients that imply a positive mutual correlation at a confidence level of 95 percent or greater were obtained for silver, zinc, lead, coppar, and boron. In stream-sediment and soil sampl?s, similar correlations at the 95-percent confidence le-rel were evident for silver, copper, and lead. In rock samples, strong positive correlations were noted for two groups of elements; these are (1) silver, gcid, arsenic, cadmium, copper, lead, antimony, and zinc, and (2) calcium, boron, chromium, lanthan $n$, scandium, vanadium, and yttrium.

\section{GEOPHYSICS}

Previous and current regional studies of gravity and magnetics were reviewed to ascertain their 
applicability to the mineral resource assessment. The roadless area has been covered by a regional gravity survey in progress for the Butte $1^{\circ} \times 2^{\circ}$ quadrangle (Hassemer and Hanna, 1982). Because of the wide spacing of the gravity stations relative to the size of the roadless area, the Bouguer anomaly map of the roadless area is relatively featureless. The map shows that the Royal stock coincides with a weak negative gravity anomaly. The area is also within that of a regional aeromagnetic survey (Douglas, 1973), but the results can be used only to discriminate large features such as the Royal stock, which coincides with a strong, circular positive magnetic anomaly.

\section{MINING DISTRICTS AND MINERALIZED AREAS}

\section{History and geologic setting of deposits}

The Dolus Lakes Roadless Area is in one of the richest mineral-producing regions of Montana. Since the discovery of gold in Gold Creek in 1852, the first reported from Montana, mining of 15 districts in the Flint Creek Range has had an estimated aggregate value of $\$ 120$ million (actual value at time of production; compiled from USGS Mineral Resource Data System (MRDS) records). Philipsburg is the most important of these districts (fig. 1), having a production of about $\$ 100$ million (compiled from MRDS records), principally of silver and manganese, and lesser amounts of zinc, lead, gold, and copper. Other important districts in the Flint Creek Range are the Pioneer district (fig. 1), having a production of about $\$ 7$ million in gold from placer deposits (Lyden, 1948); the Dunkleberg district, having about $\$ 1.9$ million production (compiled from MRDS records), mainly of lead and silver; and the Princeton (Boulder Creek) district, having a production of about $\$ 1.6$ million (compiled from MRDS recrods) of mainly gold, silver, and lead. In addition, the Douglas Creek (Gird Creek) district has produced a significant amount of phosphate.

Identified resources of tungsten and phosphate have been reported for other parts of the Flint Creek Range (Erickson and others, 1981), southwest of the Dolus Lakes Roadless Area: (1) mineral exploration by Union Carbide Corp. has identified about 1 million tons of tungsten resources averaging more than 0.6 percent $\mathrm{WO}_{3}$ in skarn along the contact of the Royal stock near the head of Boulder Creek, and additional tungsten resources may also occur in other parts of the Flint Creek Range Wilderness Study Area; and (2) the existence of about 25 million tons of paramarginal resources of phosphate rock was estimated on the basis of results of exploration by Cominco American, Inc. In addition, mineral exploration by Noranda Exploration, Inc., has delineated a molybdenum-bearing stockwork zone in the vicinity of East Goat Mountain (Erickson and others, 1981).

Mineral deposits exploited in the past in the Flint Creek Range include placer gold; vein silver and gold (zinc and lead in places); replacement silver, zinc, and lead; replacement manganese; and stratabound phosphate deposits. In addition, contact-metasomatic tungsten and stockwork molybdenum deposits are known to exist in the Flint Creek Range (Ericksen and others, 1981). Most deposits are found near or at contacts of intrusive rocks, such as gran ?diorite, with sedimentary rocks, especially carbonates such as limestone and dolomite.

The Pioneer district adjoins the ros dless area on the northeast and includes the lower parts of Gold Creek, Pioneer Gulch, and Pikes Peak Creek (fig. 1). Mining of placer-gold deposits began in this district in 1862 and continued sporadically until abo't 1941, when dredge mining of Pioneer Gulch was susnended. The district produced an estimated $\$ 7$ million in gold. Presumably, most of the gold had its origin in vein deposits in sedimentary rocks in the roof zone of the Royal stock. These gold-bearing veins were stripped off, and the gold was deposited in glac: $x 1$ till in the area of the Pioneer district. Outwash streams and subsequent interglacial and postglarial streams reworked the till deposits, concentratin? the gold in terrace and stream gravels (Pardee, 1951).

The Rose Mountain (Gold Creek) district overlaps the roadless area, on the north (fig. 1). Most of the mines and prospects examined during thi- study are in this district. The district has produced about $\$ 100,000$ in minerals, about half of which was gold from placers in the upper sections of Gold Creek. T.e remainder was from lode deposits, principally narrow gold- and silver-bearing fissure quartz veins in granodiorite. Two mines adjacent to the roadless area, John G. Carlisle and Independence mines (sites 9 and 21, fig. 2) had minor production totaling about $\$ 12,500$, mostly in gold and silver.

\section{Examination of prospects}

Mining-claim records on file in Granite and Powell Counties indicate that 515 claims have been located in or adjacent to the roadless area; records of active claims on file in 1981 with the U. S. Bureau of Land Management totaled 74 lode claims and 7 placer claims. Thirty mines and prospects were examined and sampled during fieldwork in the roadless area; 329 samples, consisting of 277 lode and 52 plicer samples, were collected and analyzed (table 1). Analytical techniques and results for all samples are on file at the U.S. Bureau of Mines, Western Field Operations Center in Spokane, Wash. No mines in the roadless area were active in 1981.

The classification of resources for mines and prospects in the roadless area follows the guidelines in U. S. Geological Survey "Circular 831" (U. S. Bureau of Mines and U. S. Geological Survey, 1980).

Three properties within the roadless area and one adjacent to the northern boundary have indicated or inferred gold, silver, and molybdenum rerources. The most significant deposits are the $B M-C \supset R$ prospect (site 5, fig. 2), the Independence mine (site 21), the Queen (Pikes Peak) prospect (site 16), the Snow Bunny (Majestic) prospect (site 13), and the Jorn G. Carlisle mine (site 9).

The BM-COR prospect, held by Hnuston International Minerals Corp. in 1981, contains 6 million tons of indicated subeconomic molybdenum resources averaging 0.036 percent molybdenum disulfide $\left(\mathrm{MoS}_{2}\right)$. Amax Exploration, Inc., locatet a series of claims here in 1975 and drilled three test holes in 1976, which encountered molybdenum-bearing quartzpyrite veins. A new block of claims was located in this 
Table 1.--Mines and prospects in and near the Dolus Lakes Roadless Area, Powell and Granite Counties, Mont.

[Underlined names are of mines and prospects that are outside roadless area; samples analyzed by U.S. Bureau of Mines Laboratories at Reno, Nev.; gold and silver determined by fire assay; copper, zinc, and molybdenum determined by atomic absorption]

\begin{tabular}{|c|c|c|c|}
\hline $\begin{array}{l}\text { No. } \\
\text { in } \\
\text { fig. }\end{array}$ & Name & Workings & Sample and resource data \\
\hline 1 & $\frac{\text { Mountain Top }}{\text { prospect. }}$ & $\begin{array}{l}\text { Six adits (two caved), } \\
\text { two pits. }\end{array}$ & $\begin{array}{l}\text { Mineralized quartz veinlets and veins strike } N .60^{\circ}-80^{\circ} \text { W. and } \\
\text { dip } 60^{\circ}-80^{\circ} \text { SW. along faults and shear zones in granodiorite. } \\
\text { One chip sample of } 13 \text { contained } 0.86 \mathrm{oz} \text { gold and } 0.86 \mathrm{oz} \\
\text { silver per ton. Two others contained } 0.51 \mathrm{oz} \text { and } 0.63 \mathrm{oz} \\
\text { gold per ton. }\end{array}$ \\
\hline 2 & Nellie prospect---- & Two caved aditsm-n & $\begin{array}{l}\text { Iron-stained shear zone in granodiorite trends } \mathrm{N} .67^{\circ} \mathrm{W} . ; \text { dip } \\
\text { near vertical. No metals detected in five chip samples. }\end{array}$ \\
\hline 3 & $\begin{array}{l}\text { American Beauty } \\
\text { prospect. }\end{array}$ & $\begin{array}{l}\text { Two caved shafts, } \\
21 \text { trenches and } \\
\text { pits. }\end{array}$ & $\begin{array}{l}\text { Numerous quartz veins containing pyrite and molybdenite, trend } \\
\mathrm{N} .10^{\circ}-60^{\circ} \mathrm{E} \text {. and dip } 3^{\circ}-35^{\circ} \text { E. in silicified, iron-stainet, } \\
\text { sericitized shear zones in granodiorite. of four chip } \\
\text { samples from an } 80-\mathrm{ft}-1 \text { ong trench, one contained as much as } \\
0.04 \mathrm{oz} \text { gold and } 2.36 \mathrm{oz} \text { silver per ton. A chip sample from } \\
\text { one pit contained } 0.58 \mathrm{oz} \text { silver per ton. }\end{array}$ \\
\hline 4 & New York prospect-m & One pit-m-nמ-m & One grab sample contained 0.05 percent molybdenum disulfide. \\
\hline 5 & BM-COR prospect-m & $\begin{array}{l}\text { Three drill holes } \\
\text { and eight pits. }\end{array}$ & $\begin{array}{l}\text { A quartz-pyrite vein stockwork occurs in biotite granodiorite. } \\
\text { Drill data delineated a pie-shaped mineralized zone } \\
180-580 \mathrm{ft} \text { below the surface; it is } 1,300 \mathrm{ft} \text { in length and } \\
\text { contains about } 6 \mathrm{mil1} \text { ion tons of indicated subeconomic } \\
\text { resources averaging } 0.036 \text { percent molybdenum disulfide. }\end{array}$ \\
\hline 6 & $\begin{array}{l}\text { Hawkeye, Florence, } \\
\text { and Josephine } \\
\text { prospect. }\end{array}$ & $\begin{array}{l}\text { One caved shaft, six } \\
\text { trenches, eleven } \\
\text { pits. }\end{array}$ & $\begin{array}{l}\text { Quartz veinlets, lenses, and veins as much as } 3.0 \mathrm{ft} \text { thick } \\
\text { along shear zones in altered granodiorite. One select } \\
\text { sample contained } 0.01 \mathrm{oz} \text { gold and } 1.0 \mathrm{oz} \text { silver per ton. }\end{array}$ \\
\hline 7 & $\frac{\text { Blue Streak No. } 2}{\text { Prospect. }}$ & $\begin{array}{l}\text { One } 20-f t-\text { long adit } \\
\text { opens on a } 40-f t- \\
\text { long cut. Two caved } \\
\text { adits, a water-filled } \\
\text { shaft, several pits } \\
\text { and trenches. }\end{array}$ & $\begin{array}{l}\text { Two shear zones in granodiorite trend N. } 60^{\circ} \mathrm{E} . \text {, dipping } 65^{\circ} \mathrm{SE} \text {.; } \\
\text { and } \mathrm{N} .66^{\circ} \mathrm{W} . \text {, dipping } 67^{\circ} \text { SW. The zones are hydrothermally } \\
\text { altered and include quartz veins containing pyrite. of six } \\
\text { chip samples, one from the face of the open adit contained } \\
0.65 \text { oz gold and } 0.74 \text { oz silver per ton. A select sample of } \\
\text { the shaft stockplle contained } 0.77 \text { oz gold and } 0.80 \text { oz sijver } \\
\text { per ton. }\end{array}$ \\
\hline 8 & Neversweat prospect- & One 35-ft-long trench- & $\begin{array}{l}\text { A near-vertical, iron-stained shear zone strikes } \mathrm{N} .20^{\circ} \mathrm{W} \text {. } \\
\text { through altered, sericitized granodiorite. No significant } \\
\text { metal content in samples. }\end{array}$ \\
\hline 9 & John G. Carlisle mine & $\begin{array}{l}\text { Five caved adits, one } \\
\text { trench, one pit. }\end{array}$ & $\begin{array}{l}\text { A } 10-f t-w i d e \text { shear zone trends } N .50^{\circ} \mathrm{W} \text {. and dips } 75^{\circ} \mathrm{sW} \text {. } \\
\text { Quartz veins, as thick as } 1.25 \mathrm{ft} \text { and containing copper, } \\
\text { gold, and silver minerals, are heavily iron stained. One } \\
\text { select sample contained } 0.13 \text { oz gold and } 0.99 \text { oz siliver per } \\
\text { ton, and } 2.56 \text { percent zinc. Three others contained from } 0.01 \\
\text { to } 0.09 \text { oz gold per ton and } 0.26 \text { to } 0.99 \text { oz silver per tor. }\end{array}$ \\
\hline 10 & $\begin{array}{l}\text { Lost One (Clear } \\
\text { Grit) prospect. }\end{array}$ & $\begin{array}{l}\text { One caved adit, five } \\
\text { trenches, two } \\
\text { shafts, and seven } \\
\text { pits. }\end{array}$ & $\begin{array}{l}\text { Iron-stained quartz stringers and velns trend } \mathrm{N} .30^{\circ}-70^{\circ} \mathrm{W} \text {. } \\
\text { and dip } 85^{\circ} \text { SW. along a hydrothermally altered shear zone } \\
\text { in granodiorite. The zone is cut by fractures trending } \\
\mathrm{N} .70^{\circ} \mathrm{E} \text {. Sulfide minerals occur sporadically in quartz } \\
\text { veins associated with the shear zone. Twenty-one samples } \\
\text { were collected; } 15 \text { contained from } 0.01 \text { to } 1.33 \text { oz gold and } \\
\text { from } 0.01 \text { to } 0.99 \mathrm{oz} \text { silver per ton. }\end{array}$ \\
\hline
\end{tabular}




\begin{tabular}{|c|c|c|c|}
\hline $\begin{array}{l}\text { No. } \\
\text { in } \\
\text { fig. }\end{array}$ & Name & Workings & Sample and resource data \\
\hline 11 & Mudhole prospect-- & $\begin{array}{l}\text { Two trenches, one } \\
\text { pit, one open cut. }\end{array}$ & $\begin{array}{l}\text { Quartz veins containing pyrite and limonite in silicified, } \\
\text { iron-stained, sericitized granodiorite. Two faults trend } \\
\mathrm{N} .72^{\circ} \mathrm{E} \text {. and } \mathrm{N} .75^{\circ} \mathrm{W} \text {; the first dips } 57^{\circ} \mathrm{SE} \text {, and the } \\
\text { second is nearly vertical. of three chip samples, one } \\
\text { contained } 0.1 \text { oz gold per ton; one grab sample contained } \\
0.3 \text { oz silver per ton. }\end{array}$ \\
\hline 12 & $\begin{array}{l}\text { September Snow } \\
\text { prospect. }\end{array}$ & $\begin{array}{l}\text { Three adits and } \\
\text { one trench. }\end{array}$ & $\begin{array}{l}\text { Shear zones trend N. } 45^{\circ}-80^{\circ} \text { W. and dip } 40^{\circ}-46^{\circ} \text { SW. in } \\
\text { granodiorite. Iron-stained quartz veins are in the } \\
\text { hydrothermally altered shear zones. One select sample from } \\
\text { a stockpile contained } 0.05 \text { oz gold and } 1.15 \text { oz silver per } \\
\text { ton. Three chip samples from an adit averaged } 1.16 \mathrm{oz} \\
\text { silver per ton. }\end{array}$ \\
\hline 13 & $\begin{array}{l}\text { Snow Bunny } \\
\text { (Majestic) } \\
\text { prospect. }\end{array}$ & $\begin{array}{l}\text { One partially caved } \\
\text { adit, four caved } \\
\text { shafts, four } \\
\text { trenches, and } \\
\text { nine pits. }\end{array}$ & $\begin{array}{l}\text { Sulfide minerals occur in quartz veins along a shear zone } \\
\text { that averages } 2.8 \mathrm{ft} \text { long and is as much as } 31 \text { ft wide. } \\
\text { The zone trends } \mathrm{N} \text {. } 30^{\circ}-70^{\circ} \mathrm{W} \text {. and dips } 80^{\circ} \mathrm{sW} \text {. Thirteen chip } \\
\text { samples and nine select or grab samples were collected. An } \\
\text { inferred marginal reserve based on chip samples totals } 49,000 \\
\text { tons averaging } 0.09 \text { oz gold per ton and } 0.25 \text { oz silver per } \\
\text { ton. }\end{array}$ \\
\hline 14 & Lancaster prospect-- & One pit-_- & $\begin{array}{l}\text { Iron-stained quartz veinlets in granodiorite. One grab sample } \\
\text { contained a trace of silver. }\end{array}$ \\
\hline 15 & Comet prospect- & One caved shaft-_- & $\begin{array}{l}\text { A siliceous, sericitic, and blotitic shear zone trends N. } 60^{\circ} \mathrm{W} \text {. } \\
\text { and dips } 57^{\circ} \text { sW. along a fault in granodiorite. One select } \\
\text { sample contained a trace of gold and } 0.5 \text { oz silvar per ton. }\end{array}$ \\
\hline 16 & $\begin{array}{l}\text { Queen (PIkes Peak) } \\
\text { prospect. }\end{array}$ & $\begin{array}{l}\text { One } 190-f t-1 \text { ong adit, } \\
\text { one caved adit. }\end{array}$ & $\begin{array}{l}\text { Iron- and manganese-stained quartz veins trend } N .30^{\circ}-80^{\circ} \mathrm{W} \text {. } \\
\text { and dip } 60^{\circ}-80^{\circ} \mathrm{SW} \text {. along shear zones in granodiorite. } \\
\text { About } 8,000 \text { tons of marginal reserves average } 0.09 \text { oz gold } \\
\text { and } 9.4 \mathrm{oz} \text { silver per ton. }\end{array}$ \\
\hline 17 & Nugget prospect- & One 80-ft-long adtt-- & $\begin{array}{l}\text { A fractured quartz vein along a shear zone trends } \mathrm{N} .42^{\circ} \mathrm{W} \text {. } \\
\text { and dips } 85^{\circ} \mathrm{NE} \text {; five chip samples averaged } 0.0^{\circ} \text { oz gold } \\
\text { and } 0.29 \text { oz silver per ton. }\end{array}$ \\
\hline 18 & Dewey prospect- - & One pit- & $\begin{array}{l}\text { A } 0.2-\text { ft-thick quartz vein along a sericitized shepr zone in } \\
\text { granodiorite. One chip sample contained a trace of gold } \\
\text { and silver. }\end{array}$ \\
\hline 19 & Gilt Edge prospect- & One 24-ft-1ong trench & $\begin{array}{l}\text { A 1.0-ft-thick shear zone in sericitized granodiorite. One } \\
\text { chip sample assayed a trace of gold and silver. }\end{array}$ \\
\hline 20 & Amethyst prospect-- & One 26-ft-long trench & $\begin{array}{l}\text { A quartz vein trends } N_{.} 58^{\circ} \text { W. and dips } 75^{\circ} \text { sw.; another } \\
\text { strikes } N .60^{\circ} \text { E. and dips } 50^{\circ} \text { NW. along iron-stained, } \\
\text { silicified shear zones in granodiorite. One chip sample } \\
\text { contained a trace of gold and silver. }\end{array}$ \\
\hline 21 & Independence mine-- & $\begin{array}{l}\text { Five open adits and } \\
\text { one caved adit, } \\
\text { one trench. }\end{array}$ & $\begin{array}{l}\text { Sulfide mf nerals occur in a quartz vein that trends } \mathrm{N} .50^{\circ}- \\
70^{\circ} \mathrm{W} \text {. and dips } 55^{\circ}-70^{\circ} \mathrm{SW} \text {. The vein is along a steeply } \\
\text { dipping shear zone in granodiorite. Indicated and inferred } \\
\text { marginal reserves of } 8,100 \text { tons average } 0.44 \mathrm{oz} \text { gold and } \\
0.60 \mathrm{oz} \text { silver per ton. }\end{array}$ \\
\hline
\end{tabular}


Table 1.--Mines and prospects in and near the Dolus Lakes Roadless Area, Powell and Granite Counties, Mont.- Continued

\begin{tabular}{|c|c|c|c|}
\hline $\begin{array}{l}\text { No. } \\
\text { in } \\
\text { fig. } 2\end{array}$ & Name & Workings & Sample and resource data \\
\hline 22 & Blue Diamond prospect & One 15-ft-long trench & $\begin{array}{l}\text { Hydrothermally altered and serfcitized granodiorite. One grab } \\
\text { sample contained a trace of gold and silver. }\end{array}$ \\
\hline 23 & $\begin{array}{l}\text { Bluebird Claim } \\
\text { prospect. }\end{array}$ & $\begin{array}{l}\text { One } 20 \text {-ft-long adit, } \\
\text { one pit. }\end{array}$ & $\begin{array}{l}\text { A quartz velnlet less than } 0.1 \text { ft thick occurs in a shear zone } \\
\text { trending } \mathrm{N} .67^{\circ} \text { W. and dipping } 60^{\circ} \mathrm{SW} \text {. In granodlorite. One } \\
\text { grab sample assayed } 1.05 \text { oz gold and } 0.83 \text { oz silver per ton. }\end{array}$ \\
\hline 24 & $\begin{array}{l}\text { Edwin E. Graupner } \\
\text { prospect. }\end{array}$ & One pit-_ & $\begin{array}{l}\text { Iron-stalned quartz vein trends } \mathrm{N} .35^{\circ} \mathrm{W} \text {. and dips } 81^{\circ} \mathrm{NE} \text {. In } \\
\text { granodiorite. No significant metal content. }\end{array}$ \\
\hline 25 & Big Bill prospect-- & One $160-f t-1$ ong adit- & $\begin{array}{l}\text { A quartz vein as much as } 1.6 \mathrm{ft} \text { wide trends } \mathrm{N} .40^{\circ} \mathrm{W} \text {. with a } \\
\text { nearly vertical dip along a shear zone in granodiorite. Nis } \\
\text { significant metal content. }\end{array}$ \\
\hline 26 & $\begin{array}{l}\text { Cosmopolitan } \\
\text { prospect. }\end{array}$ & $\begin{array}{l}\text { One 5-ft-long adit, } \\
\text { one caved adit, one } \\
\text { 33-ft-long trench. }\end{array}$ & $\begin{array}{l}\text { A 1.0-ft-thick quartz vein trends N. } 45^{\circ} \mathrm{W} \text {. and dips } 65^{\circ} \mathrm{NE} \text {. } \\
\text { in granodiorite. No significant metal content. }\end{array}$ \\
\hline 27 & Decelver prospect--- & One 25-ft-1ong shaft- & $\begin{array}{l}\text { A } 0.5-\mathrm{ft} \text {-thick quartz vein containing copper minerals trends } \\
\mathrm{N} .35^{\circ} \mathrm{W} \text {. and dips } 64^{\circ} \mathrm{SW} \text {. along a shear zone in granodiorite. } \\
\text { One grab sample contalned } 0.4 \text { oz silver per ton. One chip } \\
\text { sample contained } 0.3 \text { oz silver per ton and } 0.28 \text { percent comper }\end{array}$ \\
\hline 28 & Dolo prospect- & One caved adtt-_-_-_ & $\begin{array}{l}\text { Calcite stringers in limestone near contact with granodiorite. } \\
\text { One grab sample contained a trace of gold. }\end{array}$ \\
\hline 29 & Cougar prospect-- & One pit-_-_ & $\begin{array}{l}\text { A skarn layer at the contact between marble and granodiorite. } \\
\text { One chlp sample contained no significant metal concentrations. }\end{array}$ \\
\hline 30 & Schramm prospect- - & $\begin{array}{l}\text { One } 1,400-f t-1 \text { long } \\
\text { adit, one caved adit. }\end{array}$ & $\begin{array}{l}\text { Subterranean stream deposit along fractures in } 1 \text { imestone. } \\
\text { Two placer-type samples of sediments contalned less than } \\
10 \text { cents per cu yd in gold (at } \$ 400 \text { per oz gold per ton). }\end{array}$ \\
\hline
\end{tabular}


area in 1979-1980 by Houston International Minerals Corp. in response to favorable geochemical data that they had collected. The molybdenum-bearing zone is associated with a quartz-pyrite stockwork within the biotite granodiorite of the Royal stock.

The Independence mine, about $1,500 \mathrm{ft}$ outside the roadless area, contains 8,100 tons of indicated and inferred marginal reserves, which average $0.44 \mathrm{oz}$ gold per ton and $0.60 \mathrm{oz}$ silver per ton. U.S. Bureau of Mines records show that between 1926 and 1935, 481 oz of gold, $197 \mathrm{oz}$ of silver, and $189 \mathrm{lb}$ of copper were produced from this mine. Marginal reserves of gold and silver are in a quartz vein averaging $0.8 \mathrm{ft}$ thick that trends N. $50^{\circ}-70^{\circ} \mathrm{W}$. and dips $55^{\circ}-70^{\circ} \mathrm{sW}$. along a shear zone in granodiorite. Boxwork limonite is associated with the vein, and sericitized halos surround most veins.

The Queen (Pikes Peak) prospect contains 8,000 tons of marginal reserves in quartz veins that average $0.09 \mathrm{oz}$ gold per ton and $9.4 \mathrm{oz}$ silver per ton. An adit $190 \mathrm{ft}$ long follows quartz veins that trend N. $30^{\circ}-80^{\circ}$ W. and dip $60^{\circ}-80^{\circ} \mathrm{SW}$. along a shear zone in granodiorite. Veins of varying widths are exposed for $170 \mathrm{ft}$ in the adit, and the mineralized zone has an average thickness of $3.3 \mathrm{ft}$.

The Snow Bunny (Majestic) prospect contains 49,000 tons of inferred marginal reserves in quartz veins that average $0.09 \mathrm{oz}$ gold per ton and $0.25 \mathrm{oz}$ silver per ton. Workings include a partially caved adit open for $27 \mathrm{ft}$ from the portal, four caved shafts having depths from 6 to $12 \mathrm{ft}$, and numerous pits and trenches. The mineralized and altered shear zone was traced for $1,100 \mathrm{ft}$ in a northwesterly direction. The richest segment is $750 \mathrm{ft}$ long and averages $2.1 \mathrm{ft}$ thick.

The John G. Carlisle mine, about 1,000 ft outside the roadless area, is on a group of four claims that were patented in 1902. Between 1897 and 1899, about $120 \mathrm{oz}$ of gold and some silver was recovered from ore mined from the main workings. A 600-ft-long adit followed quartz veins that trend N. $50^{\circ}$ W. and dip $75^{\circ}$ SW, in a shear zone in granodiorite (Emmons and Calkins, 1913). The zone is as wide as $10 \mathrm{ft}$. In 1981 , five caved adits, one 20-ft-long trench, and a small pit were on the claims. The mine has been inactive for about $\mathbf{4 0}$ years.

The Queen, Snow Bunny, and John G. Carlisle deposits appear to occur along the same shear zone, but the valley between the Queen and Snow Bunny prospects contains glacial till that prevents verification of the continuity.

\section{ASSESSMENT OF MINERAL RESOURCE POTENTIAL}

\section{Commodities}

The assessment of mineral resource potential of the roadless area is focused principally on several commodities that are found there. These are gold, silver, molybdenum, tungsten, copper, lead, and zinc. Anomalously high concentrations of these elements occur in stream-sediment, panned-concentrate, and rock samples collected during the geochemical survey and in samples from mines and prospects. The roadless area probably does not have potential for resources of manganese, bismuth, arsenic, antimony, beryllium, and cadritm, ?though such elements were present in anomalous amounts in many samples. However, the distribution and levels of concentration of these elements are important because these elements commonly are parts of element suites that are characteristic of certain hydrothermal deporit types in the roadless area. They are regarded as pathfinder elements because they are associated with, or are dispersed around, deposits of commodity elements such as gold, silver, molybdenum, tungsten, conper, lead, and zinc.

Other commodities in the roadless area are dolomite and limestone for cement, granotiorite for building stone, and sand and gravel for aggregate. Such materials, however, are more readil' available elsewhere in more accessible locations and closer to markets. Phosphate leases extend a short distance into the roadless area, but, although phos?hate rock occurs on Emery Ridge north of the roadless area, none was found within it. Oil and gas lease applications have been made for most of the roadless area, but the potential for occurrence of oil or gas resources in the roadless area is low. Plutonic igneous rocks are exposed over most of the roadles: area, and the surrounding sedimentary rocks have been heated to such high temperatures that any oil or gas generated would have been destroyed or driven to cooler parts of the sedimentary section. No coal or geothermal energy resources are known.

\section{Potential for mineral resources}

The potential of various parts of the roadless area for resources is rated as high, moderate, or low on the basis of the degree to which favoral le criteria are met. Resources are classed either as identified, as determined in the examination of mines and prospects, or as undiscovered, on the basis of the interpretation of geological, mines and prospects, drilling, and geochemical data and observations. The denosit types that are listed for each area are based on known deposits in the roadless area or on ore-depoit models, defined by known occurrences, that fit the geologic, geochemical, and geophysical characteristirs of each area. The favorable criteria used in this rating include:

(1) The occurrence of mines and pros rects: the kinds of deposits and the abundance of prosp ?cts.

(2) The occurrence of geochemical anomalies: the specific elements and their concentration ranges, the kinds of media sampled, the number of anomalous samples, and the consideration of suites of anomalous elements as representatives of particular types of deposits.

(3) Favorable geology: the presence of favorable host rocks and favorable structural settin?, and the presence of igneous rocks or degree of priximity of igneous rocks that could have been heat or metal sources or could have been hosts to deposits.

The roadless area contains two subaraas having high potential for resources and two subaraas having moderate potential; the remainder of the roadless area has low potential. The resulting interpretation of the mineral resource potential is shown in trble 2 and figure 2. Undiscovered resources are expected to occur as stockwork (or porphyry), vein, skarn, and placer deposits.

Area 1 is a zone trending northwest from the vicinity of Pikes Peak to Rose Mountain. It includes five prospects in the roadless area and one mine and 
Table 2.--Characterist1cs of areas of mineral resource potential, Dolus Lakes Roadless Area,

Powe 11 and Granite Counties, Mont.

\begin{tabular}{|c|c|c|c|c|c|}
\hline Area & $\begin{array}{l}\text { Resource } \\
\text { potential }\end{array}$ & $\begin{array}{l}\text { Identified } \\
\text { resources }\end{array}$ & $\begin{array}{l}\text { Undiscovered } \\
\text { resources }\end{array}$ & $\begin{array}{l}\text { Deposit } \\
\text { types }\end{array}$ & Favorable criteria \\
\hline 1 & High-س-س & $\begin{array}{l}\text { Gold, } \\
\text { silver. }\end{array}$ & $\begin{array}{l}\text { Gold, silver, } \\
\text { molybdenum. }\end{array}$ & Vein, stockwork & $\begin{array}{l}\text { 1. Occurrence of known deposits. } \\
\text { 2. Geochemical anomalies in resource elements } \mathrm{Au}, \mathrm{Ag}, \mathrm{Mr}, \\
\mathrm{Cu}, \mathrm{Pb}, \mathrm{Zn}, \mathrm{W} \text {, and in pathfinder elements } \mathrm{Bi}, \mathrm{Sb}, \mathrm{As}, \mathrm{Cd} \text {. } \\
\text { 3. Favorable geology consisting of velns along northwest- } \\
\text { trending zone of fracturing in granodiorite. Alteration } \\
\text { along veins and shear zones. }\end{array}$ \\
\hline 2 & HIgh- & Mo1ybdenum & $\begin{array}{l}\text { Molybdenum, } \\
\text { gold, } \\
\text { silver. }\end{array}$ & Stockwork, vein & $\begin{array}{l}\text { 1. Occurrence of known deposits. } \\
\text { 2. Geochemical anomalies in resource elements } \mathrm{Au}, \mathrm{Ag}, \mathrm{Cr} \text {, } \mathrm{Pb}, \mathrm{Zn}, \mathrm{Mo}, \mathrm{W} \text {, and In pathfinder elements } \mathrm{As}, \mathrm{Sn} \text {, and } \mathrm{Sb} \text {. } \\
\text { 3. Favorable geology consisting of velns in granodiorite } \\
\text { and altered rock along velns. }\end{array}$ \\
\hline 3 & Moderate & None & $\begin{array}{l}\text { Mo1ybdenum, } \\
\text { gold, } \\
\text { sllver. }\end{array}$ & $\begin{array}{l}\text { Stockwork, } \\
\text { vein, placer. }\end{array}$ & $\begin{array}{l}\text { 1. Occurrence of prospects. } \\
\text { 2. Geochemical anomalies in resource elements } \mathrm{Ag}, \mathrm{Cu}, \mathrm{P}^{\mathrm{h}} \text {, } \\
\mathrm{Zn}, \mathrm{Mo}, \mathrm{W} \text {, and in pathfinder elements } \mathrm{Sn}, \mathrm{BI}, \mathrm{Sb}, \mathrm{Cd}, \mathrm{Mn} \text {. } \\
\text { 3. Favorable geology consisting of (1) sparse veins and aiter- } \\
\text { ation in granodiorite, (2) surflcial sediments in } \\
\text { valleys that drain areas of gold-bearling veins. }\end{array}$ \\
\hline 4 & Moderate & None & $\begin{array}{l}\text { Tungsten, } \\
\text { gold, } \\
\text { silver, } \\
\text { molybdenum. }\end{array}$ & $\begin{array}{c}\text { Skarn, veln, } \\
\text { placer, } \\
\text { stockwork. }\end{array}$ & $\begin{array}{l}\text { 1. Geochemical anomalies in resource elements } \mathrm{W}, \mathrm{Au}, \mathrm{Ag}, \mathrm{Mo} \text {, } \\
\mathrm{Cu}, \mathrm{Zn} \text {, and in pathfinder elements } \mathrm{Mn}, \mathrm{Be}, \mathrm{Bl} \text {. } \\
\text { 2. Favorable geology conslsting of (1) contact zone of } \\
\text { granodiorite and Paleozoic carbonate rocks, and (2) } \\
\text { presence of surficial deposits in valley that drains } \\
\text { area of gold-bearing velns. }\end{array}$ \\
\hline 5 & Low-m--- & None & $\begin{array}{l}\text { Tungsten, } \\
\text { gold, } \\
\text { silver, } \\
\text { molybdenum. }\end{array}$ & $\begin{array}{c}\text { Skarn, vein, } \\
\text { placer, } \\
\text { stockwork. }\end{array}$ & $\begin{array}{l}\text { 1. Occurrence of prospects. } \\
\text { 2. Favorable geology consisting of (1) sparse veins in } \\
\text { granodiorite, (2) contact zone of granodiorite } \\
\text { and Paleozolc carbonate rocks, and (3) presence of } \\
\text { surficlal deposits in valley that drains area of } \\
\text { gold-bearing velns. }\end{array}$ \\
\hline
\end{tabular}


two prospects outside but near the northern border. Two prospects in the roadless area, the Snow Bunny and Queen, have identified resources of gold and silver. The known deposits are small and occur as northwest-trending, narrow quartz veins and mineralized shear zones that parallel the principal attitude of joints and minor faults in the granodiorite stock. Rock samples of many small, mineralized quartz veins and fractures in granodiorite were analyzed and found to contain anomalously high concentrations of gold, silver, copper, lead, zinc, arsenic, antimony, bismuth, and cadmium; these concentrations indicate high potential for the occurrence of gold and silver resources in additional vein deposits. Several of these rock samples also were anomalous in molybdenum; this characteristic indicates a low potential for the occirrence of stockwork molybdenum resources at depth in the roadless area.

Area 2, the Tolean Lake-Game Pass area, includes the $B M-C O R$ prospect, having identified resources of molybdenum; three other prospects in the roadless area; and one prospect outside but near the boundary. Rock samples from area 2 are anomalous in gold, silver, molybdenum, tungsten, copper, lead, zinc, arsenic, tin, and antimony. Elements that were present in anomalously high concentrations in streamsediment and soil samples from area 2 are silver, molybdenum, zinc, lead, and copper. Pannedconcentrate samples were anomalous in molybdenum, tungsten, and zinc. This geochemical evidence and the occurrence in drill holes and prospect workings of mineralized veins having altered envelopes indicate a high potential for the occurrence of molybdenum resources in stockwork deposits and gold and silver resources in vein deposits.

Area 3 covers much of the roadless area; it contains, within the roadless area, nine prospects and one mine with identified resources and also four prospects outside, but adjacent to, the northern boundary. Area 3 is underlain entirely by granodiorite, and known deposits are much like those in area 1 , mostly mineralized veins and shear zones in granodiorite. Small quartz veins, commonly about 1 to 6 in. wide, are numerous in exposures along ridge tops; these veins strike mostly northwesterly and dip to the southwest. Rock samples, principally from these veins, contained anomalously high concentrations of silver, molybdenum, copper, zinc, lead, tungsten, antimony, tin, bismuth, and cadmium. Sediment samples from streams draining this area were anomalously high in silver, copper, lead, zinc, cadmium, molybdenum, tungsten, manganese, and bismuth. Panned-concentrate samples ware found to be anomalous in molybdenum, tungsten, silver, zinc, and bismuth. Compared to areas 1 and 2, however, the values of these elements are generally lower, the veins are narrower and fewer, and alteration is less evident. Area 3 has moderate potential for the occurrence of molybdenum resources in stockwork deposits and gold and silver in vein deposits.

Area 3 also includes surficial glacial and alluvial deposits along Rock, Dolus, and Pikes Peak Creeks. Because of the occurrence of gold-bearing veins in areas that these streams drain, area 3 has moderate potential for the occurrence of gold resources in placers.

Although much of area 4 is coverec' by surficial deposits, favorable geology consisting of a contact zone between granodiorite and Paleozoic carbonate rocks is inferred. Such a contact zone is especially favorable when the intrusive rock projects into tine sedimentary rocks and when the sedimentary rocks are carbonate rocks that are highly fractured due to folding and faulting. These conditions ar? inferred to exist in area 4. The contact zone here may be similar to that at the head of Boulder Creek, about $4 \mathrm{mi}$ southwest of the roadless area, where skarn tungsten deposits of possible ore grade occur in the contact zone between the Royal stock and Paleozcic carbonate rocks (Ericksen and others, 1981). Evidence of mineralization in area 4 comes from a rock sample collected from near Rock Creek Lake that contained anomalously high concentrations of a suit $\epsilon$. of elements consistent with the occurrence of skern tungsten deposits, including tungsten, molybdenum, gold, copper, manganese, and beryllium. Stre?m-sediment samples from this area contained anomalous amounts of zinc and silver, and one panned conrentrate was anomalous in molybdenum, tungsten, an zinc. Like area 3, area 4 has surficial deposits that may contain placer-gold deposits. Area 4 has moderrte potential for the occurrence of resources in skarn tungsten, vein gold and silver, placer gold, and stockwork molybdenum deposits.

Area 5, the northeastern part of the roadless area, has three prospects but no geochemical anomalies. Favorable geology consints of the occurrence of sparse veins in granodiorits and in the contact zone between granodiorite and Faleozoic and Mesozoic sedimentary rocks, much of which is limestone. The area also includes surfirial deposits that may contain placer-gold deposits. Area 5 has low potential for the occurrence of resources in skarn tungsten, vein gold and silver, and stockwork molybdenum deposits. 


\section{REFERENCES CITED}

Allen, J. C., Jr., 1966, Structure and petrology of the Royal stock, Flint Creek Range, central-western Montana: Geological Society of America Bulletin, v. 77, p. 291-302.

Baty, J. B., 1976, Fission-track age dates from three granitic plutons in the Flint Creek Range, western Montana: Northwest Geology, v. 5, p. 34-41.

Benoit, W. R., 1974, Chemistry and genetic relationship of the Royal stock and Mount Powell batholith, western Montana: Northwest Geology, v. 3, p. 53-58.

Douglas, J. K., 1973, Geophysical investigations of the Montana lineament: Missoula, University of Montana, M.S. Thesis, 75 p.

Emmons, W. H., and Calkins, F. C., 1913, Geology and ore deposits of the Philipsburg quadrangle, Montana: U.S. Geological Survey Professional Paper 78, $271 \mathrm{p}$.

Ericksen, G. E., Leinz, R. W., and Marks, L. Y., 1981, Mineral resources of the Flint Creek Range Wilderness Study Area, Granite and Powell Counties, Montana: U.S. Geological Survey Open-File Report 81-1095, 6 p.

Hassemer, J. H., and Hanna, W. F., 1982, Slides showing preliminary mosaic magnetic and complete Bouguer gravity anomaly maps of the Butte $1^{\circ} \times 2^{\circ}$ quadrangle, Montana: U.S. Geological Survey Open-File Report 82-603.
Lyden, C. J., 1948, The gold placers of Montana: Montana Bureau of Mines and Geology Memoir 26, $152 \mathrm{p}$.

Mutch, T. A., 1960, Geologic map of the nor'. zast flank of the Flint Creek Range, wistern Montana: Montana Bureau of Mines and Geology Special Publication 22 (Geologic Map 5).

Pardee, J. T., 1951, Gold placer deposits of the Pioneer district, Montana: U.S. Geolngical Survey Bulletin 978-C, p. 69-99.

Ruppel, E. T., Wallace, C. A., Schmidt, R. G., and Lopez, D. A., 1981, Preliminary interpretation of the thrust belt in southwest and west-contral Montana and east-central Idaho, in Guideb nok to southwest Montana: Montana Geological Scriety, Field Conference and Symposium, 1981, p. 139159.

Streckeisen, A. L., 1975, To each plutonic rork its proper name: Earth-Science Reviews, 12, p. 133.

U.S. Bureau of Mines and U.S. Geological Survey, 1980, Principles of a resource/reserve classification for minerals: U.S. Geological Survey Circular 831,5 p..

VanTrump, George, Jr., and Miesch, A. T., 1977, The U.S. Geological Survey RASS-STATPAC rystem for management and statistical reduction of geochemical data: Computers and Geosciances, v. 3, p. 475-488. 